\title{
Effect of migration on employment (A case study of district Hangu, Pakistan)
}

\author{
Muhammad Arafat* \\ Institute of development study (IDS) University of agriculture Peshawar, Pakistan \\ *Corresponding author E-mail:arafateconomist@gmail.com
}

\begin{abstract}
When a person leave his/her home place and migrate to other place, he/she may call emigrant. This paper deals with effect of migration on employment. The study was carried out to investigate the pre and post occupation of emigrants. Primary data was conducted from two villages of district Hangu, namely Shnawari and Darband through questionnaire and descriptive statistic was used to achieve the objectives. It is concluded that emigration has significant effect on employment opportunity, before emigration $45.58 \%$ people were jobless and the figure dropdown to $1.36 \%$ after migration. Most of them are drivers and majority of emigrants have qualified up to matric. They have skill but lack of technical training and the remittance they send have a significant impact on household income.
\end{abstract}

\section{Introduction}

Migration phenomenon is as old as human kind and the process of migration increase as the world becoming fast by the invention of most advance technology and communication system. The flow of international migrants has increase annually due to globalization and considered the countries boundary is just an imaginary boundary (ILO, 2005). It was recorded 244 million migrants in Dec 2015, which was 41 million in 2000; showing and $71 \%$ increase (UN, 2015).

All the countries are not alike in all the resources. Some are capital rich and some are labour rich countries. The lack of employment opportunities and low per capita income push the people toward migration. The emigrants exploring better job abroad and send remittance to home which substantial increase the per capita income of emigrant families. The per capita income of remittance receiver families is $45 \%$ more than those of non-remittance receiver and it was $64 \%$ for the case of urban households (Asif, 2013). It was considered key source of income and assets generation and enhanced consumption expenditure of families of emigrants that accelerate development process which is beneficial for entire community. (Tariq et.al, 2013). It play an important role in bringing prosperity, eliminating poverty by improving living standard, social and economic status, and also have significant positive impact on education, health and recreation of the remittance recipient families.(Ali et.al, 2013)

Pakistan play significant role in South Asia to export their labour force. The numbers of Pakistani employment abroad were reached to $8,803,226$ (GoP, 2012). From Pakistan, due to poor employment opportunities, people leave their origin place and bulk amount of labour force has been migrated to Gulf countries ( $\mathrm{Ku}$ wait, Oman, Qatar, Bahrain) and Saudi Arabia (Vaqar, 2012). While some people also migrated for the purpose of enjoying peaceful environment and getting high salaried job.
Despite some positive impact of migration there seems to be negative impact also both on migrant sender and receiver countries. First, the immigrant sending remittance has a significant negative contribution on human capital formation. Parental absence has a negative impact to check children activities which is offsetting of remittance in the form of inflow of income. In the absence of parent or elders their children get free, that influence their home activities (Hassan, 2013) and the outflow of talented and skilled persons (brain drain) has no contribution in the economic uplift of their home countries. Secondly, the educated and skilled native residents enjoy both the wages and employment in production sector but those native who lack of education and skill receiving a minimum wage due to competition created by emigrants (Chassamboulli \& Palivose, 2013). The study attempted to estimate the pre and post occupation of emigrants and extended the study that how much of remittance send by emigrants to their home. What factors push the people towards migration? How much time they spent abroad? An effort is made to study the age, education, skill, technical knowledge and relative abroad of emigrants at the time of migration. Lastly conclusion is drawn on the basis of results.

\section{Objectives}

- To study the effect of migration on employment opportunities of the target population.

\section{Material and method}

The proposed study was conducted in district Hangu, Pakistan. The study is confined to the effect of migration on employment of two villages of that district, namely Darband and Shnawori. These villages are purposively selected because these villages have large number of emigrants as compared to other areas of the district. The analysis is based on primary data and for that purpose an in- 
terview schedule was designed. Primary data was collected by using questionnaire from sample respondent. As the data is related to the income and occupation of the emigrants and other information of the households, so heads of the household were interviewed. The descriptive statistics and MS excel is used for achieving the pre targeted objective.

\section{Result and discussion}

\subsection{Number of emigrants per households}

The table 1 shows that $42(45.16 \%)$ families were recorded from which two person have gone abroad which is overwhelming. Following by $28(30.11 \%$ ) families from which three person have gone abroad. 15(16.12\%) families were recorded from which one person have gone abroad and $8(8.60 \%)$ families were those where one person have gone abroad to earn livelihood. The majority of households were dependant on two working member of their families to earn livelihood. Because of negligible job opportunities in their concern areas they prefer to send at least two members from their home to enhance their social and economic status through remittance.. Similar studies conducted by some other and same result have been found where mostly two person per household were emigrant. (Nasir et.al, 2011)

Table 1: Number of Emigrants per Household

\begin{tabular}{lll}
\hline Number of emigrants per household & No. & Percentage \\
\hline 1 person & 15 & 16.12 \\
2 person & 42 & 45.16 \\
3 person & 28 & 30.11 \\
Above 3 person & 8 & 8.60 \\
Total & 93 & 100 \\
\hline
\end{tabular}

Source: Field survey, 2014

\subsection{Age of emigrants}

There are many factors which effect migration decision but amongst those age is one of the prominent factor.In the table 2 it is indicated that majority of emigrants belong to the age group 3640 years. $22.17 \%$ emigrants belong to age group $31-35,17.19 \%$ belong to age group $41-45,15.83 \%$ belongs to age group 26-30, $6.78 \%$ belongs to age group $20-25$ and $11.76 \%$ emigrants belongs to age group above 45 years. The results showed that peoples spend most of their productive working age in overseas countries. Emigrants belongs to elder age group has some experience and they are enjoying the basic amenities of life and want to still live and continue their business and jobs abroad. Sadaf et al (2010) and Sattar (2009) found in their study on role of international migration in agricultural development and farmer's livelihoods in Toba Tek Singh (Pakistan) that majority of emigrants were up to 30 years of age. Their result is different from present study because of difference of location.

Table 2: Distribution of Emigrants by Age Groups

\begin{tabular}{lll}
\hline Age (Years) & No. & Percentage \\
\hline $20-25$ & 15 & 6.78 \\
$26-30$ & 35 & 15.83 \\
$31-35$ & 49 & 22.17 \\
$36-40$ & 58 & 26.24 \\
$41-45$ & 38 & 17.19 \\
Above 45 & 26 & 11.76 \\
Total & 221 & 100 \\
\hline
\end{tabular}

Source: Field survey, 2014

\subsection{Educational level of overseas workers}

In the table 3 it has shown that the greatest portion of emigrants $38 \%$ received education up to secondary level, $19 \%$ up to FA/F.Sc level, $14.47 \%$ up to middle level, $8.14 \%$ up to below middle level, $5.42 \%$ up to $\mathrm{BA} / \mathrm{BSc}$ level and $4.07 \%$ received education above $\mathrm{BA} / \mathrm{BSc}$ level. In the study area majority of emigrants completed their education up to metric level and after that they have gone abroad for earning.

Table 3: Educational Level of Overseas Workers

\begin{tabular}{lll}
\hline Education level & No. & Percentage \\
\hline Primary & 18 & 8.14 \\
Middle & 32 & 14.47 \\
Metric & 84 & 38.00 \\
FA/F.Sc & 42 & 19.00 \\
BA/BSc & 12 & 5.42 \\
Above BA/BSc & 9 & 4.07 \\
Total & 221 & 100 \\
\hline
\end{tabular}

Source: Field survey, 2014

\subsection{Reasons of emigration}

The table 4 indicates that $17.64 \%$ of emigrants were gone abroad due to poor economic conditions, $46.15 \%$ of emigrants were due to unemployment and $36.19 \%$ of emigrants were recorded that have gone abroad because of higher wages there. The Pukhtun community cannot digest the socio-economic peak of agnates (Tarboors) (Niaz et al, 2010). This is the reason that the above mentioned percent of households sent their members to overseas for the purpose of earning more money. There exist pull and push factor behind emigration (Lee, 1996). Now a day's people are not willing to move abroad just for economic reason in which most of them are labor but some also move in order to be better off abroad (Blanka, 2012). Poor economic condition and Unemployment is push factor, which push the people toward migration. Due to unemployment and for improvement in their economic condition and living standard people prefer to go abroad to earn more income (Mammona, 2001).

Table 4: Reasons of Emigration

\begin{tabular}{lll}
\hline Reasons & No. & Percentage \\
\hline Poor economic conditions & 39 & 17.64 \\
Unemployment & 102 & 46.15 \\
Higher wages & 80 & 36.19 \\
Total & 221 & 100
\end{tabular}

Source: Field survey, 2014

\subsection{Duration abroad of sample emigrants}

The table 5 classify the duration of sample emigrants that have been working out of country. The table indicates that $19 \%$ emigrants have been working abroad for 5 years, $36.65 \%$ emigrants have been working abroad for 6-10 years, $13.12 \%$ emigrants have been working abroad for 11-15 years, $17.19 \%$ emigrants have been working abroad for $16-20$ years $8.14 \%$ emigrants have been working abroad for 21-25 years and 5.88\% emigrants have been working abroad for above 25 years. A majority of emigrants $36.65 \%$ were found that has been working abroad for over 10 years. This trend indicates pliability and lenience of the workers abroad and speaks of strength of overseas job market for Pakistani workers and also the degree of their tolerability. This characteristic is also helpful in maintaining the emigration process on a sustained basis and with sustainable impact on the socio-economic conditions. The emigrant who's duration were above 25 years shows the satisfaction from their job and still want to continue their job due to high living standard, high income and other basic amenities.

Table 5: Distribution of Emigrants by Duration Abroad

\begin{tabular}{lll}
\hline Duration (years) & No. & Percentage \\
\hline Up to 5 & 42 & 19.00 \\
$6-10$ & 81 & 36.65 \\
$11-15$ & 29 & 13.12 \\
$16-20$ & 38 & 17.19 \\
$21-25$ & 18 & 8.14 \\
Above 25 & 13 & 5.88 \\
Total & 221 & 100 \\
\hline
\end{tabular}

Source: Field survey, 2014. 


\subsection{Relative abroad}

The table 6 shows that $81(87 \%)$ emigrants belongs to those households that have relatives working abroad and $12(13 \%)$ emigrants were found to those households which have no relative working abroad. In the research area most of households have some relatives working abroad. Which play an important role to motivate the people toward migration and most of the people are expected to go abroad due to their relatives.

Table 6: Emigrants with Relative Abroad

\begin{tabular}{lll}
\hline Response & No. & Percentage \\
\hline Yes & 81 & 87.09 \\
No & 12 & 12.90 \\
Total & 93 & 100 \\
\hline Source: Field survey, 2014 & &
\end{tabular}

Source: Field survey, 2014

\subsection{Technical training status of emigrants}

Technical training of the emigrants includes refrigeration, mechanics, electrician etc. The table 7 indicates that only 49(22\%) of emigrant were recorded that they have received technical training and $172(77.55 \%)$ of emigrants have not received technical training. It is expected from those emigrants who have technical training will get high salaried job as compared to those who do not receive technical training.

Table 7: Technical Training Status of Emigrants

\begin{tabular}{lll}
\hline \multirow{2}{*}{ Training received } & Overseas workers & \\
& No. & Percentage \\
\hline Yes & 49 & 22.45 \\
No & 172 & 77.55 \\
Total & 221 & 100 \\
\hline
\end{tabular}

\subsection{Skill status of emigrants}

Skill of the emigrants includes mason, carpenter, carpet-weaver, painting, fitter, driver, plumbing, brick-kilns etc. The table 8 indicates that $188(85 \%)$ of emigrants are skilled and $33(15 \%)$ of emigrants are unskilled. In skilled emigrants most of them are drivers (shown in table IX). The remaining $15 \%$ of emigrants mostly adjusted their self with labor market which does not require skill. In the research area the income of skilled emigrants are comparatively more than unskilled emigrants.

Table 8: Skill Status of Emigrants

\begin{tabular}{lll}
\multicolumn{3}{c}{ Table 8: } \\
\multirow{2}{*}{ Response } & Overseas workers & \\
& No. & Percentage \\
\hline Yes & 188 & 85.03 \\
No & 33 & 14.96 \\
Total & 221 & 100 \\
\hline
\end{tabular}

Source: Field survey 2014.

\subsection{Occupation of emigrants}

The table 9 indicates that before emigration $45.58 \%$ emigrant were jobless, $17 \%$ were engaged in farming ,7\% were driver,5\% having their own business, $8 \%$ were students, $3 \%$ are private company labor and $3 \%$ having skilled services, $5 \%$ are computer operator and $4 \%$ were working in government sector. While after emigration great change in occupation status of emigrants has been occurred. $1.36 \%$ emigrants were found jobless, student, government servant and those who engaged in farming drop down to zero, $69 \%$ were found driver which is the overwhelm in the occupation after emigrants, the percentage of private company labor reached from $3 \%$ to $13 \%$ and rest of the emigrants engaged in different occupation categories like business, computer operator/supervisor/surveyor, other skilled services.
Table 9: Occupation of Emigrants

\begin{tabular}{llll}
\hline Activity/Occupation & $\begin{array}{l}\text { Before emigra- } \\
\text { tion }\end{array}$ & $\begin{array}{l}\text { After emigra- } \\
\text { tion }\end{array}$ \\
\hline Jobless & $\begin{array}{l}45.58 \\
17.68\end{array}$ & 1.36 \\
Farming & 7.48 & 0 \\
Driver & 5.44 & 69.39 \\
Business/shop & 8.16 & 2.72 \\
Student & 3.40 & 0 \\
Labor/Private company/Waiter & 4.76 & 12.93 \\
Computer opera- & 3.40 & 10.88 \\
tor/supervisor/surveyor & 4.082 & 9.60 \\
Skilled service & 100 & 0 \\
Government service & & 100 \\
Total & & \\
\hline
\end{tabular}

Source: Field survey, 2014.

\subsection{Total monthly remittance receive by sample households}

The table 10 shows the monthly wise amount of remittance receive by households.25(26.88\%) households receive remittance between Rs 20001-40000, 23 (24.73\%) households receive remittance between Rs 40001-60000, 15 (15.78\%) households receive remittance between Rs 10000-20000, 13 (13.97\%) households receive remittance between Rs 60001-80000 and 17 (18.27\%) of households receive remittance up to one lac or above one lacs. The study shows that those who working abroad receive high income from indigenous emigrant. That increase household's average monthly income and most of the households are now enjoying high remittance. The remittance improved their socio-economic status and living standard by increasing the use of consumption durable goods and purchasing vehicles.

Table 10: Amount of Remittance Receive by Households per Month

\begin{tabular}{lll} 
RS/month & No. & Percentage \\
\hline $10000-20000$ & 15 & 15.78 \\
$20001-40000$ & 25 & 26.88 \\
$40001-60000$ & 23 & 24.73 \\
$60001-80000$ & 13 & 13.97 \\
$80001-100000$ & 11 & 11.82 \\
Above & 6 & 6.31 \\
Total & 93 & 100 \\
\hline
\end{tabular}

Source: Field survey, 2014.

\subsection{Average monthly income of emigrants}

Average monthly income of overseas workers is recorded higher than that of in-country workers. The table 11 indicates that the average monthly income of overseas workers is 61175 rupees and average monthly income of in-country workers is 9958 rupees. Both international and internal remittance reduces the level, depth and severity of poverty (Richard and Adams, 2006).

Table 11: Average Monthly Income of Emigrants Average monthly income in Pak rupees

\begin{tabular}{ll} 
Overseas & 61175 \\
In- country & 9958 \\
\hline
\end{tabular}

Source: Field survey, 2014.

\section{Conclusion}

The main factors that cause migrations are unemployment and poor economic condition. The people of the study area are curious to get education up to metric level and prefer to go abroad rather than to get highly education. They have skill but lack of technical training. The main occupation of emigrants of the study area is driving. Their economic condition is much better than before by sending their earning to home. Majority of the emigrants are young and have spent almost 10 years abroad. 


\section{References}

[1] Iqbal.A. 2013. Impact of Foreign Remittances on Household Poverty in Pakistan: Unpublished thesis of Master in Economics at UMB School of Economics and Business in Norwegian University of Life Sciences.

[2] Tariq. M, S. Khan and N.Khan 2013. Assessing utilization patterns of remittances at household level in district Peshawar, Khyber Pakhtunkhwa, Pakistan: International Journal of Arts and Commerce. Vol. 2 (4): 172-83.

[3] UN. 2015. "Trend in International Migration, 2015". UN department of Economic and Social Affairs Population Division.

[4] Ali. A, R. Khan, M. Shah and E. Zia 2013. Do remittances contribute to improvement in life standard at the host area (With reference to Chitral, KPK, Pakistan): European Journal of Business and Social Science, Vol. 2(2), 66-74

[5] Ahmad V and S. Muhammad 2014. Diaspora and Economy: Effects of the Global Economic Slowdown on Remittances. Available at http://www.slideshare.net/Vaqar_Ahmed/diaspora-and-economyeffects-of-the-global-economic-slowdown-on-remittances (accessed on April 4, 2014)

[6] S. Mamoona, 2004. "Impact of Remittances on the Socio-Economic Conditions of Rural Families in District Poonch of AJ\&K. unpublished thesis of agriculture university of Peshawar.

[7] Lee, Everret. 1996 “ A Theory of Migration” Demography 47-57

[8] W. Blanka. 2012. "Economic Aspects of Remittances and Migration". Unpublished master thesis of Charles University in Prague.

[9] Muhammad N., M. Ahmad, N. Ahmad, M. Shah, I. Alam and M Jawad. 2010. The impact of foreign remittances on the socioeconomic conditions of households (a case study of rural areas in dir lower, NWFP). Sarhad J. Agric. 26(1): 141-145.

[10] Muhmood. S, Izhar. A.K, Ashfaq. A.M, Babar. S and Siara. A. 2010. "Role of International Migration in Agricultural Development and Farmer's Livelihoods" A Case Study of Agrarian Community: Pak. J. Sci., Vol. 47(3)

[11] Nisar.M, Salman. T and Faiz. R 2011. The effect of remittance on schooling: evidence from Pakistan. PIDE Working Paper 66.

[12] Chasamboulli A. \& P Theodore 2013. "Impact of Immigration on Employment and Wages of Native Worker". Bank of Greece. Economic Research Department.

[13] Hassan M., H. Mahmood and M. Shahid. 2013. Consequences of Worker's Remittances on Human Capital: An In-Depth Investigation for a Case of Pakistan: Middle-East Journal of Scientific Research 14 (3): 443-452,

[14] GOP.2012. Foreign remittance to hit record in FY13. Ministry of Finance.Government of Pakistan. Available at http://www.pakistantoday.com.pk/2012/11/17/city/karachi/foreignremittances-to-hit-record-in-fy-13-finance-ministry /(accessed on April 4, 2014)

[15] ILO. 2005. " Migration of Health Worker: Country Case Study of Philippine Institute of Health Policy ad Development Studies, National Institutes of Health, University of the Philippines, Manila 